\title{
KONSEP EKONOMI PADA MASA KHALIFAH
}

\author{
Aninda Aprilia (90100118031) \\ anindaaprilia038@gmail.com
}

Kondisi kehidupan pada masa rasulullah saw sangatlah berbeda dengan keadaan sekarang ini. Pada masa rasulullah peperangan selalu mewarnai kehidupan masyarakat. Sehingga pada saat itu yang menjadi sumber pendapatan masyarakat adalah dari harta rampasan perang yang diperoleh dari lawan perangnya. Pada fase ketika rasulullah saw masih dimekkah, kegiatan ekonomi belum dilakukan sebab nabi saw fokus oada dakwahnya dalam rangka menguatkan ketauhidan pada orang-orang quraisy yang menyembah berhala pada waktu itu. Kegiatan ekonomi baru pada masa rasullullah terlaksana ketika nabi berada dimadinah dengan meneata pemerintahan sekaligus menata perekonomian masyarakat madinah Pada intinya ,pada zaman awal-awal islam pendapatan yang didapatkan oleh masyarakat madinahmasih sangat kecil. Diantara sumber pendapatannya pada masa itu dari harta rampasan perang,tebusan tawanan perang, pinjman dari kaum muslimin, zakat fitrah, wakaf.nawaib ( pajak bagi muslimin kaya dalam rangka menutupi pengeluaran negara maupun pada bantuan dari kaum muslimin. (Maghfiroh et al., 2020)

Pada masa pra Islam, hakam atau juru damai itu harus memenuhi beberapa kualifikasi. Di antara syarat yang terpenting bagi mereka adalah harus cakap dan memiliki kekuatan supranatural atau adikodrati. Oleh karena itu, dalam pemeriksaan dan penyelesaian persengketaan di kalangan mereka, hakam lebih banyak menggunakan kekuatan firasat daripada menghadirkan alat-alat bukti seperti saksi-saksi atau pengakuan.14 Namun setelah Islam datang dan berkembang yang dibawakan oleh Nabi Muhammad Saw, lembaga perwasitan terus berjalan dan dikembangkan sebagai alternatif penyelesaian sengketa dengan memodifikasi yang pernah berlaku pada masa praIslam. Hal-hal yang bersifat takhayul dan syirik mulai dieliminir secara bertahap dan disesuaikan dengan al-Quran dan as-Sunnah.(Rangkuti, 2011)

Abu Bakar ash-Shiddiq khalifah Rasulullah. Ia bernama Abdullah bin Abi Quhafah Utsman bin Amir bin Amr bin Ka'ab bin Sa'ad bin Taym bin Murrah bin Ka'ab bin Lu'ay bin Ghalib, alQurasyi, at-Tamimi. Nasabnya bertemu dengan nasab Rasulullah di kakeknya, Murrah.15 Musha'ab bin Zubair dan yang lainnya berkata: Kaum muslimin sepakat menamakannya sebagai ash-Shiddiq. Sebab dialah orang yang pertama kali dan yang bersegera menyatakan kebenaran Rasulullah, serta selalu bersikap jujur dan benar Ibnu Katsir berkata: Abu Bakar adalah sahabat yang paling baik bacaannya-yakni dia yang paling mengerti tentang al-Quran. Sebab Rasulullah menjadikannya sebagai imam shalat para sahabat sambil bersabda, "Orang yang menjadi imam adalah orang yang paling baik bacaannya tentang Kitab Allah”.17 Imam Tirmidzi meriwayatkan dari 
Aisyah, dia berkata, Rasulullah bersabda: "Tidak selayaknya seseorang dari suatu kaum untuk menjadi imam padahal di tengah-tengah mereka ada Abu Bakar" Selain paling mengerti tentang al-Quran, dia juga adalah orang yang paling paham tentang sunnah. Tatkala para sahabat menanyakannya banyak hal, dia selalu menampakkan kepakarannya dengan menukilkan hadis dari Rasulullah. Dia menghafalnya dan menghadirkan sunnah itu tatkala dihajatkan dan diperlukan.

Dia juga salah seorang yang tercerdik diantara para sahabat.18 Tamam ar-Razi dalam kitab alFawaid dan Ibnu Asakir dari Abdullah bin Amr bin al-Ash, dia berkata, Saya mendengar Rasulullah bersabda: Jibril datang menemuiku dan berkata: Sesungguhnya Allah memerintahkan kamu untuk meminta pendapat Abu Bakar (Muchtar, 2016)

Kebijakan Umar dalam masalah zakat diklasifikasikan menjadi tiga bagian. Pertama, pendapat beliau seputar objek zakat. Kedua, pendapat beliau mengenai penarikan zakat. Ketiga, pendapat beliau seputar pendistribusian dan pemberdayaan zakat. Kebijakan Umar bin Khattab dalam Penetapan Objek Zakat Penetapan Objek Zakat Pada Harta yang Berkembang, Umar bin Khattab memiliki beberapa fatwa terkait dengan syarat harta berkembang menjadi objek zakat, di antaranya adalah penetapan perhiasan yang terbuat dari emas dan perak sebagai objek zakat.11 Umar juga menetapkan syarat penggembalaan bagi hewan ternak, seperti kambing, sapi, dan unta. Hal ini menjadi alasan bahwa hewan ternak tersebut sejatinya dimaksudkan untuk dikembangbiakkan di padang yang luas, bukan untuk semata-maka konsumsi harian pemilik gembalaan.Harta Zakat yang Dikeluarkan Didasari Atas Prinsip Taisir (Kemudahan) Umar bin Khattab menerapkan prinsip taisir (memberi kemudahan) kepada para muzaki yang hendak mengeluarkan zakat hartanya. Dengan prinsip taisir ini, beliau membolehkan mengeluarkan pengganti dari harta yang harus dikeluarkan sebagai zakat.(Aqbar, n.d.) 


\section{DAFTAR PUSTAKA}

Maghfiroh, Z., Siti, D., Caniago, A., Ekonomi, P., Pada, I., Peradaban, M., Saw, R., Equiliberium, W., Pemikiran, J., \& Ekonomi, P. (2020). Analisis sejarah pemikiran ekonomi islam masa klasik" IQTISHADIA, Vol 8 No 2 2016, 2. 8(2), 2-3.

Muchtar, E. H. (2016). Perkembangan Tasyri' Ekonomi Pada Masa Khulafa „Urrasyidin. Jurnal Asy-Syukriyyah, 17(December 2016), 54-70.

Rangkuti, R. Y. (2011). Sistem Penyelesaian Sengketa Ekonomi Islam: Instrumen Penting bagi Konsep Ekonomi Islam Mendatang. AsySyir'ah: Jurnal Ilmu Syari'ah Dan Hukum, Vol 45(2). http://asysyirah.uin-suka.com/index.php/AS

Aqbar, K. (n.d.). Kata Kunci : Zakat; Kebijakan; Umar bin Khattab. 